\title{
Identification of the source of blood meals in mosquitoes collected from north-eastern Australia
}

Narayan Gyawali ${ }^{1,2,3^{*}}$, Andrew W. Taylor-Robinson ${ }^{4}$, Richard S. Bradbury ${ }^{1}$, David W. Huggins ${ }^{5}$, Leon E. Hugo ${ }^{3}$, Kym Lowry ${ }^{2}$ and John G. Aaskov²

\begin{abstract}
Background: More than 70 arboviruses have been identified in Australia and the transmission cycles of most are poorly understood. While there is an extensive list of arthropods from which these viruses have been recovered, far less is known about the non-human hosts that may be involved in the transmission cycles of these viruses and the relative roles of different mosquito species in cycles of transmission involving different hosts. Some of the highest rates of human infection with zoonotic arboviruses, such as Ross River (RRV) and Barmah Forest (BFV) viruses, occur in coastal regions of north-eastern Australia.
\end{abstract}

Methods: Engorged mosquitoes collected as a part of routine surveillance using $\mathrm{CO}_{2}$-baited light traps in the Rockhampton Region and the adjoining Shire of Livingstone in central Queensland, north-eastern Australia, were analysed for the source of their blood meal. A 457 or 623 nucleotide region of the cytochrome $b$ gene in the blood was amplified by PCR and the amplicons sequenced. The origin of the blood was identified by comparing the sequences obtained with those in GenBank ${ }^{\circledR}$.

Results: The most common hosts for the mosquitoes sampled were domestic cattle (26/54) and wild birds (14/54). Humans (2/54) were an infrequent host for this range of mosquitoes that are known to transmit arboviruses causing human disease, and in an area where infections with human pathogens like RRV and BFV are commonly recorded. The blood meals identified in the most abundant vector analysed, Culex annulirostris, were from 10 different vertebrate hosts. The notable detection of chimpanzee blood in two mosquitoes, presumably obtained from a nearby zoo, extends the known range of hosts for this species. Culex quinquefasciatus and Cx. sitiens fed almost exclusively on a variety of bird species.

Conclusions: While human-mosquito-human transmission of arboviruses like RRV can occur, this study highlights the potential importance of zoonotic cycles of transmission, including avian species, of arboviruses that are indigenous to Australia. Further studies on larger samples of blood-engorged mosquitoes are required to validate the trends observed herein. Moreover, serological and virological evidence that the hosts on which the mosquitoes are feeding are being infected with arboviruses of interest are required.

Keywords: Arbovirus, Mosquito, Culex, Blood meal, Host, Transmission, Australia

\footnotetext{
*Correspondence: Narayan.Gyawali@qimrberghofer.edu.au

1 School of Health, Medical \& Applied Sciences, Central Queensland

University, Rockhampton, QLD 4701, Australia

Full list of author information is available at the end of the article
} 


\section{Background}

Arboviruses (arthropod-borne viruses) are transmitted between hosts by arthropod vectors. While they may infect more than one vertebrate host [1], only some hosts develop viraemias high enough to infect the vectors that feed on them. Australia is home to approximately 380 species of mammals [2], including an estimated 235 species of native marsupials [3]. In addition, 890 species of native and migratory birds have been recorded [4], along with more than 300 species of mosquito [5].

Significant vectors of arboviruses in Australia, including Aedes camptorhynchus, Ae. notoscriptus, Ae. vigilax and Culex annulirostris, feed on a range of animal species, including native birds, domestic animals, marsupials and humans [6-11]. However, the composition of animal communities and their proximity to mosquitoes also influence mosquito feeding patterns [12]. In order to determine the health risks associated with individual mosquitoes and to better understand the ecology of mosquito-borne pathogens, it is informative to determine the blood feeding preferences of mosquitoes. Additionally, in order to formulate effective management strategies to control arboviral diseases, it is important to understand the broader ecology and transmission cycles of arboviruses in the areas where this is to happen. A key consideration is what animals are hosts for potential arboviral vectors.

North-eastern Australia is, largely, a tropical region where both mosquito vectors and vertebrate hosts are abundant and in which an ongoing expansion of the human population is predicted [13]. The area chosen for this study is representative of urban and semi-urban areas in north-eastern Australia where several medically relevant mosquito-borne viruses are endemic and acquisition of clinical infections with Ross River (RRV) and Barmah Forest (BFV) viruses is common [14]. The Fitzroy River, one of the longest in Australia, divides the study region from west to east and features a dam that separates tidal salt water downstream from fresh water upstream. Rain and tidal inundation of this river basin contribute to ideal breeding sites for many species of mosquitoes.

\section{Methods}

Mosquitoes were collected in CDC light traps incorporating $\mathrm{CO}_{2}$ as a secondary mosquito attractant $\left(\mathrm{CO}_{2}\right.$-baited light trap) [15]. Industrial grade $\mathrm{CO}_{2}$ was released at a flow rate of $0.5-1.0$ litres/min from gas cylinders (BOC Lindey Group, Rockhampton, QLD, Australia). Collections were carried out at urban and semi-urban localities in the coastal Capricornia region $\left(22^{\circ} 3^{\prime} 3.6^{\prime \prime} \mathrm{S}\right.$, $148^{\circ} 11^{\prime} 20.4^{\prime \prime}$ E; Fig. 1). Trap sites were positioned in Emu Park, Gracemere, Keppel Sands, Kinka Beach, Nerimbera, North Rockhampton, South Rockhampton and
Yeppoon between January and April in 2015 and 2016. Collections were performed as part of the year round routine mosquito control programs undertaken by the Vector Management Unit of the neighbouring Livingstone Shire Council and Rockhampton Regional Council. Mosquito traps were operated overnight and samples collected the following morning. Blood-fed mosquitoes were selected, identified to species and stored at $-80{ }^{\circ} \mathrm{C}$ until required for analysis.

A modification of the protocol of Flies et al. (2016) was employed for identification of the mosquito blood meals [16]. Mosquitoes were scanned under a stereo microscope for abdomens that contained blood. These were separated from the head and thorax using a new sterile scalpel blade for each insect and transferred to $2 \mathrm{ml}$ ' $\mathrm{O}$ ' ring screw capped tubes containing three glass beads (0.5 mm each), $180 \mu \mathrm{l}$ ATL buffer (tissue lysis buffer, Qiagen, Hilden, Germany) and $20 \mu \mathrm{l}$ proteinase K (Qiagen). The tubes were incubated at $56{ }^{\circ} \mathrm{C}$ for $30 \mathrm{~min}$ and then were shaken on a MiniBeadbeater ${ }^{\mathrm{TM}}$ cell disrupter (BioSpec, Bartlesville, OK, USA). DNA was extracted from the homogenised material using a DNeasy ${ }^{\circledR}$ Blood and Tissue Kit (Qiagen) according to the manufacturer's instructions. Briefly, $200 \mu \mathrm{l}$ buffer AL (lysis buffer) was added to the homogenised material, vortexed and incubated at $56{ }^{\circ} \mathrm{C}$ for $10 \mathrm{~min}$. Following the incubation, $200 \mu \mathrm{l}$ ethanol $(100 \%)$ was added and the mixture was pipetted into a DNeasy Mini spin column (Qiagen) in a $2 \mathrm{ml}$ collection-tube and centrifuged at $6000 \times g$ for $1 \mathrm{~min}$ in a Microfuge ${ }^{\circledR} 18$ (Beckman Coulter, California, USA). Five hundred microlitres of buffer AW1 was added and the spin column centrifuged again for $1 \mathrm{~min}$ at $6000 \times g$. Buffer AW2 $(500 \mu \mathrm{l})$ was added to the spin column and centrifuged for $3 \mathrm{~min}$ at $20,000 \times g$. Between each procedure, the flow-through and collection-tube were discarded and replaced by a new collection tube. DNA was eluted by adding $50 \mu \mathrm{l}$ elution buffer to the centre of the spin column, followed by centrifugation for $1 \mathrm{~min}$ at $6000 \times g$. Eluted DNA was stored at $-20{ }^{\circ} \mathrm{C}$.

A segment of the cytochrome $b$ gene in the DNA from the blood meal was amplified using $5 \mu \mathrm{l}$ DNA, $2.5 \mu \mathrm{l}(2$ $\mathrm{mM}$ ) of each forward and reverse primer (Table 1), and 12.5 $\mu \mathrm{l} \mathrm{Taq}$ PCR master mix (Qiagen) in a final volume of $25 \mu \mathrm{l}$. For both primer sets (vertebrate [17] and mammalian [18]) the cycling conditions comprised initial denaturation at $94{ }^{\circ} \mathrm{C}$ for $3 \mathrm{~min}$, followed by 34 cycles of $94{ }^{\circ} \mathrm{C}$ for $30 \mathrm{~s}$ (denaturation), $56{ }^{\circ} \mathrm{C}$ for $30 \mathrm{~s}$ (annealing), $72{ }^{\circ} \mathrm{C}$ for $40 \mathrm{~s}$ (extension), and a final extension at $72{ }^{\circ} \mathrm{C}$ for $10 \mathrm{~min}$.

PCR products $(5 \mu \mathrm{l})$ were visualised on a $1.5 \% \mathrm{w} / \mathrm{v}$ agarose Tris-acetate/EDTA (TAE) gel stained with SYBR $^{\mathrm{TM}}$ Safe Nucleic Acid Staining Solution (ThermoFisher Scientific, Seventeen Mile Rocks, QLD, 


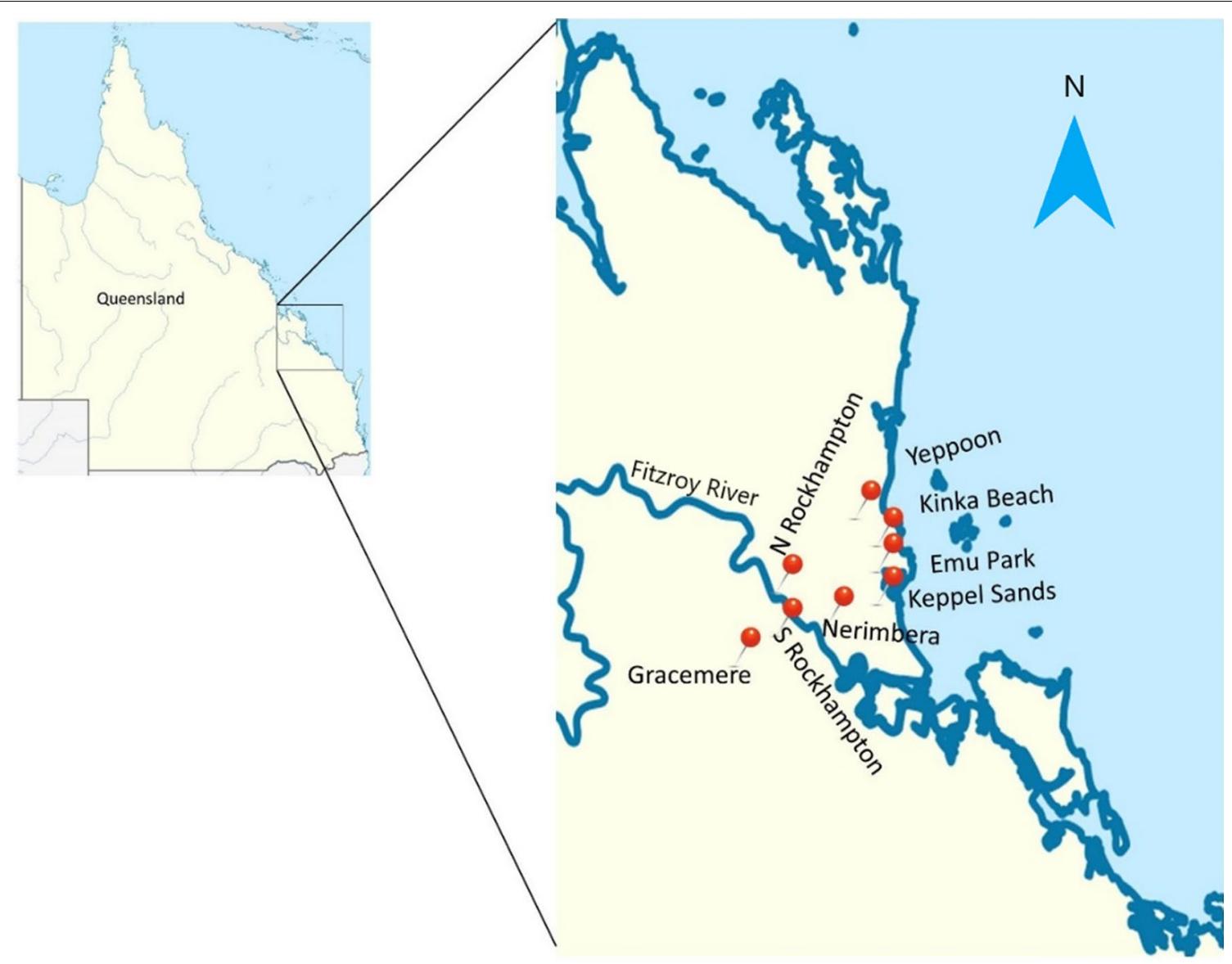

Fig. 1 Locations in eastern Central Queensland at which mosquitoes were collected for this study

Table 1 Primers used for the amplification of the cytochrome $b$ gene of mitochondrial DNA in mosquito blood meals

\begin{tabular}{lll}
\hline Primer & Sequence (5'-3') & $\begin{array}{l}\text { Amplicon } \\
\text { length } \\
(\mathrm{bp})\end{array}$ \\
\hline VF & GAGGMCAAATATCATTCTGAGG & 457 \\
VR & TAGGGCVAGGACTCCTCCTAGT & 457 \\
MAMF & TGAGGACAAATATCATTCTGAGG & 623 \\
MAMR & GGTTGTCCTCCAATTCATGTTA & 623 \\
\hline
\end{tabular}

Abbreviations: $\mathrm{VF}$, vertebrate forward; $\mathrm{VR}$, vertebrate reverse; $\mathrm{MAMF}$, mammalian forward; MAMR, mammalian reverse

Australia). Primers, unincorporated dNTPs, enzymes, and salts from the PCR reaction were removed from amplicons using a Purelink ${ }^{\circledR}$ PCR Purification Kit (Invitrogen, Life Technologies, Mulgrave, VIC, Australia) prior to amplicon sequencing. Sanger nucleotide sequencing of the amplified DNA was performed by the Analytical Facility at the QIMR Berghofer Medical Research Institute, Brisbane, QLD, Australia using an Applied Biosystems ${ }^{\circledR} 3130$ (4-capillary) Genetic Analyzer (ThermoFisher). Sequences were assembled using de novo sequence assembly software (version 10) from Geneious (Biomatters Ltd., Auckland, New Zealand) and screened against the NCBI database using the Basic Local Alignment Search Tool (BLAST: https ://blast.ncbi.nlm.nih.gov/Blast.cgi). Sample sequences with $>95 \%$ identity to sequences in GenBank ${ }^{\circledR}$ were considered a match for the given species [17].

The protocols used for DNA extraction and PCR were validated using horse and dog blood provided by Dr Juliana Chiruta from the School of Biomedical Sciences, Queensland University of Technology and using sheep blood-engorged mosquitoes and non-bloodengorged mosquitoes (colonised Ae. aegypti from Cairns, QLD, Australia) provided by Dr Gregor Devine, Mosquito Control Laboratory, QIMR Berghofer Medical Research Institute (data not shown). 


\section{Results}

A total of 7069 male and female mosquitoes from 20 species were collected in the immediate post-rainfall season months (February to April) of 2015 and 2016. Culex annulirostris was the most abundant mosquito trapped (81.9\%), followed by Ae. vigilax (6\%). Eighty-one females (1.14\%) from six species (Table 2, marked by asterisk) had a discernible red, brown or black mass in a distended abdomen and were selected as, potentially, containing blood.

Cytochrome $b$ DNA was amplified from only 10 putative blood-fed mosquitoes following PCR using universal vertebrate or mammalian primers. A second round of PCR using $5 \mu \mathrm{l}$ amplicon template from the first PCR reaction yielded cytochrome $b$ DNA in an additional 53 samples. In 18 of 81 putative blood-fed mosquitoes, no vertebrate or mammalian cytochrome $b$ DNA was amplified. Of the remaining 63 abdomens examined, cytochrome $b$ DNA was amplified from 16 using vertebrate primers, in 10 using mammalian primers and in 37 abdomens using both vertebrate and mammalian primers.

Sequencing of amplicon DNA including that derived by employing both vertebrate primers and mammalian primers resulted in the identification of the source of

Table 2 Mosquitoes collected in eastern Central Queensland in 2015 and 2016 for this study

\begin{tabular}{lll}
\hline Species & No. of specimens & $\begin{array}{l}\text { Percentage of } \\
\text { total catch (\%) }\end{array}$ \\
\hline Aedeomyia catasticta & 39 & 0.6 \\
Aedes annulirostris & 200 & 2.8 \\
Aedes kochi & 12 & 0.2 \\
Aedes lineatopennis & 251 & 3.6 \\
Aedes alternans & 2 & 0.0 \\
${ }^{*}$ Aedes vigilax & 422 & 6.0 \\
${ }^{*}$ Aedes vittiger & 76 & 1.1 \\
${ }^{*}$ Aedes notoscriptus & 43 & 0.6 \\
Anopheles annularis & 13 & 0.2 \\
Coquillettidia xanthogaster & 80 & 1.1 \\
Culex australicus & 20 & 0.3 \\
*Culex annulirostris & 5792 & 81.9 \\
Culex gelidus & 5 & 0.1 \\
*Culex quinquefasciatus & 11 & 0.2 \\
*Culex sitiens & 42 & 0.6 \\
Culex tritaeniorhynchus & 4 & 0.1 \\
${ }^{*}$ Mansonia uniformis & 36 & 0.5 \\
Mimomyia elegans & 1 & 0.0 \\
Tripteroides atripes & 9 & 0.1 \\
Uranotaenia nivipes & 11 & 0.2 \\
Total & 7069 & 100 \\
\hline
\end{tabular}

*Blood-fed mosquitoes were recovered from these mosquito species blood meals from 54 mosquitoes. These sequences were more than $95 \%$ homologous with mammalian or other vertebrate cytochrome $b$ gene sequences in GenBank (Table 3). Sequences for cytochrome $b$ DNA from two additional blood meals most closely resembled Centropus bengalensis (lesser coucal, a species of cuckoo, 91\% identity) and Equus caballus (horse, 81\% identity). However, these values were below the $95 \%$ identity proposed as a cut-off [17], so were not included in subsequent analyses. The chromatograms for these two sequences contained multiple peaks at several loci suggestive of blood meals from more than one species. Cytochrome $b$ DNA sequences from the remaining seven samples most closely resembled those from species of mosquito. DNA for these particular samples were amplified by mammalian but not by vertebrate primers.

The most common hosts for the mosquitoes sampled were domestic cattle $(26 / 54)$, followed by wild birds $(14 / 54)$. The source of blood meals identified in 39/54 $C x$. annulirostris originated from 10 different vertebrate hosts, including a major portion (59\%) from cattle. Notably, blood meals from two chimpanzees were identified in $C x$. annulirostris. The only reptile blood was identified as a blood meal of $C x$. sitiens, while the other five samples originated from avian species. Similarly, all four blood meals identified in $C x$. quinquefasciatus, also originated from birds. The locations where the mosquitoes with identified blood meals were collected are indicated in Table 4.

\section{Discussion}

Most blood meals in mosquitoes were from animals other than humans despite the collections being undertaken in representative areas of urban and semi-urban human habitations of north-eastern Australia. Given that the region accounts for a large proportion, i.e. $\sim 40 \%$, of Australia's notifications of infections of humans with RRV and BFV [14], the putative hosts of RRV, marsupials (kangaroos and wallabies in particular [19-22]) were expected to be better represented in mosquito blood meals. Hence, the relative absence of blood meals from members of the kangaroo family may reflect the low abundance of these marsupials in the region from which the mosquitoes were collected. Previous studies have found macropod blood in similar mosquito species to those studied here $[11,23]$ and a high prevalence of antibodies against RRV and other arboviruses in macropods [19-22], indicating that they are being exposed to mosquito-borne viruses. While other trapping methods may have sampled different mosquito species or increased the yield of some of the less well represented species in this collection ( $80 \%$ of which were $C x$. annulirostris), there were no major omissions of mosquito species that have 
Table 3 Sources of blood meals identified in mosquitoes collected in eastern Central Queensland

\begin{tabular}{|c|c|c|c|c|c|c|c|c|c|}
\hline \multirow{2}{*}{$\begin{array}{l}\text { Common } \\
\text { host name }\end{array}$} & \multirow[t]{2}{*}{ Host species } & \multicolumn{7}{|c|}{ Mosquito species } & \multirow{2}{*}{$\begin{array}{l}\text { Total blood } \\
\text { meal sources } \\
\text { identified }\end{array}$} \\
\hline & & Cx. annuli & Cx. quinque & CX. sitiens & $\begin{array}{l}\text { Man. } \\
\text { uniformis }\end{array}$ & Ae. vigilax & Ae. vittiger & $\begin{array}{l}\text { Ae. } \\
\text { notoscriptus }\end{array}$ & \\
\hline Human & Homo sapiens & 2 & 0 & 0 & 0 & 0 & 0 & 0 & \multirow{8}{*}{$\begin{array}{c}\text { Mammals } \\
(39 / 54)\end{array}$} \\
\hline Chimpanzee & $\begin{array}{l}\text { Pan troglo- } \\
\text { dytes }\end{array}$ & 2 & 0 & 0 & 0 & 0 & 0 & 0 & \\
\hline Cattle & Bos taurus & 23 & 0 & 0 & 0 & 2 & 1 & 0 & \\
\hline $\begin{array}{l}\text { Brushtail pos- } \\
\text { sum }\end{array}$ & $\begin{array}{l}\text { Trichosurus } \\
\text { vulpecula }\end{array}$ & 1 & 0 & 0 & 0 & 0 & 0 & 0 & \\
\hline Deer & $\begin{array}{l}\text { Rusa timor- } \\
\text { ensis }\end{array}$ & 1 & 0 & 0 & 0 & 0 & 0 & 0 & \\
\hline Horse & Equus caballus & 3 & 0 & 0 & 1 & 0 & 0 & 0 & \\
\hline Pig & Sus scrofa & 2 & 0 & 0 & 0 & 0 & 0 & 0 & \\
\hline Wallaby & $\begin{array}{l}\text { Macropus } \\
\text { agilis }\end{array}$ & 0 & 0 & 0 & 0 & 0 & 0 & 1 & \\
\hline $\begin{array}{l}\text { Carpet } \\
\text { python }\end{array}$ & $\begin{array}{l}\text { Morelia spilota } \\
\text { imbricata }\end{array}$ & 0 & 0 & 1 & 0 & 0 & 0 & 0 & Reptile (1/54) \\
\hline Butcher bird & $\begin{array}{l}\text { Cracticus } \\
\text { torquatus }\end{array}$ & 0 & 2 & 1 & 0 & 0 & 0 & 0 & Birds (14/54) \\
\hline $\begin{array}{l}\text { Australian } \\
\text { magpie }\end{array}$ & $\begin{array}{l}\text { Gymnorhina } \\
\text { tibicen }\end{array}$ & 1 & 1 & 0 & 0 & 0 & 0 & 0 & \\
\hline $\begin{array}{l}\text { Australian } \\
\text { raven }\end{array}$ & $\begin{array}{l}\text { Corvus coro- } \\
\text { noides }\end{array}$ & 2 & 0 & 2 & 0 & 0 & 0 & 0 & \\
\hline Cuckoo & $\begin{array}{l}\text { Centropus } \\
\text { bengalensis }\end{array}$ & 0 & 1 & 0 & 0 & 0 & 0 & 0 & \\
\hline Fig bird & $\begin{array}{l}\text { Sphecotheres } \\
\text { vieilloti }\end{array}$ & 1 & 0 & 0 & 0 & 0 & 0 & 0 & \\
\hline Heron & $\begin{array}{l}\text { Butorides } \\
\text { striata }\end{array}$ & 0 & 0 & 2 & 0 & 0 & 0 & 0 & \\
\hline Pelican & $\begin{array}{l}\text { Pelecanus con- } \\
\text { spicillatus }\end{array}$ & 1 & 0 & 0 & 0 & 0 & 0 & 0 & \\
\hline \multicolumn{2}{|c|}{$\begin{array}{l}\text { Proportion of mosquitoes } \\
\text { with identified blood meal }\end{array}$} & $\begin{array}{l}39 / 5792 \\
(0.67 \%)\end{array}$ & 4/11 (36\%) & $6 / 42(14.2 \%)$ & $1 / 36(2.7 \%)$ & 2/422 (0.47\%) & $1 / 76(1.3 \%)$ & $1 / 43$ (2.3\%) & \\
\hline
\end{tabular}

Abbreviations: Ae., Aedes; Cx., Culex; Man., Mansonia; Cx., annuli, Culex annulirostris; Cx. quinque, Culex quinquefasciatus

Table 4 Locations in eastern Central Queensland where blood-fed mosquitoes were trapped

\begin{tabular}{|c|c|c|c|c|c|c|c|c|c|}
\hline \multirow[t]{2}{*}{ Mosquito species } & \multicolumn{9}{|c|}{ Number of mosquitoes with the source of the blood meal identified } \\
\hline & *Emu Park & *Keppel Sands & *Kinka Beach & *Yeppoon & \#Gladstone & \#Gracemere & \#Nerimbera & $\begin{array}{l}\text { \#North } \\
\text { Rockhampton }\end{array}$ & $\begin{array}{l}\text { \#South } \\
\text { Rockhampton }\end{array}$ \\
\hline Culex annulirostris & 2 & 1 & 1 & 2 & 3 & 5 & 6 & 14 & 5 \\
\hline $\begin{array}{l}\text { Culex quinquefas- } \\
\text { ciatus }\end{array}$ & 0 & 0 & 2 & 0 & 0 & 0 & 0 & 0 & 2 \\
\hline Culex sitiens & 0 & 1 & 0 & 0 & 0 & 0 & 0 & 1 & 4 \\
\hline Mansonia uniformis & 0 & 0 & 0 & 0 & 0 & 1 & 0 & 0 & 0 \\
\hline Aedes vigilax & 0 & 0 & 0 & 1 & 0 & 0 & 0 & 1 & 0 \\
\hline Aedes vittiger & 0 & 0 & 0 & 0 & 0 & 0 & 0 & 0 & 1 \\
\hline Aedes notoscriptus & 0 & 0 & 0 & 0 & 0 & 0 & 0 & 1 & 0 \\
\hline $\begin{array}{l}\text { Proportion of mos- } \\
\text { quitoes with blood } \\
\text { meal identified }\end{array}$ & $\begin{array}{l}2 / 585 \\
* 10 / 3089\end{array}$ & $2 / 590$ & $3 / 1279$ & $3 / 635$ & $\begin{array}{l}3 / 405 \\
\# 44 / 3980\end{array}$ & $6 / 815$ & $6 / 915$ & $17 / 844$ & $12 / 1001$ \\
\hline
\end{tabular}


been implicated in transmission of arboviruses known to cause human disease in this area.

A preference of $C x$. quinquefasciatus and $C x$. sitiens for avian hosts (Table 3) has not been reported previously. There is a body of literature that suggests that $C x$. quinquefasciatus is an opportunistic feeder which acquires blood from a diverse range of birds and mammals, depending upon the relative abundance and availability of vertebrate hosts within a specific geographical area [24-28]. While this provides an insight into vector preferences, the low number of blood-fed mosquitoes collected (reflecting the well-known difficulty of sampling mosquitoes at this life stage due to their preference to rest while digesting blood meals) does not permit a conclusive determination of mosquito host preferences. Earlier studies $[9,11,23]$ that identified a significant number of $C x$. annulirostris containing avian blood meals lacked the technology to identify from which avian species the blood was derived.

Although there is serological evidence of infection of birds with a range of indigenous Australian arboviruses [29], only a limited number of viruses have been recovered from them: RRV from the Australian magpie (Grallina cyanoleuca), jacky winter (Microeca fascinans) and masked finch (Poephila personata); Kunjin virus from the green oriole (Oriolus flavocinctus) and Alfuy virus from the coucal (Centropus phasianus) [30]. Since a number of Australian arboviruses have been isolated from $C x$. quinquefasciatus [31, 32] and Cx. sitiens [33], it is possible that these arboviruses may have been maintained in transmission cycles which involve birds as hosts and $C x$. quinquefasciatus or $C x$. sitiens as vectors. A novel observation in the present study was blood originating from a carpet python (Morelia spilota) in a Cx. sitiens mosquito, although there are reports of other Culex species feeding on snakes in the USA [34].
Blood meals from approximately $80 \%$ of these mosquitoes were from mammals, predominantly cattle (Table 3 ). A range of vertebrates, including humans, horses, cattle, dogs, marsupials and birds, have been suggested as hosts for $C x$. annulirostris (Table 5), depending on the accessibility of each. The high proportion of blood meals from cattle but not from either small domestic pets (cats or dogs) or native animals (e.g. marsupials) may reflect the greater accessibility of these large hosts to the mosquitoes, especially as cattle farming is a leading industry in eastern Central Queensland. As $C x$. annulirostris has a flight range of up to $7 \mathrm{~km}[35,36]$, those specimens sampled in this study may have fed on hosts some considerable distance from where they were trapped. Current observations suggesting a potential role for cattle in the ecology of Australian arboviruses are supported by serological evidence of bovine infection with arboviruses [37-42], and also by the isolation of arboviruses from $C x$. annulirostris [10, 43-45].

The promiscuous feeding habits of $C x$. annulirostris were exemplified by the detection of non-human primate blood in two mosquitoes. As there are no non-human primate species native to Australia, these were almost certainly derived from the five common chimpanzees (Pan troglodytes) held at the Rockhampton zoo, which houses the only chimpanzees in Queensland. The closest collection site was approximately 800 metres from the zoo.

Identification, by PCR and sequencing, of mitochondrial cytochrome $b$ DNA from vertebrates in mosquito blood meals is more sensitive and specific than employing enzyme linked immunosorbent assays or gel diffusion for this purpose [46]. There was a lower rate of blood meal identification in this study $(\sim 70 \%)$ than in some other investigations employing molecular techniques where identification rates from 80 to $100 \%$ were

Table 5 Mosquito vectors and vertebrate hosts revealed by previous Australian mosquito blood-meal analysis studies

\begin{tabular}{|c|c|c|c|c|}
\hline Reference & $\begin{array}{l}\text { Locations of mosquitoes } \\
\text { sampled }\end{array}$ & Method of detection & $\begin{array}{l}\text { Most abundant blood-fed } \\
\text { vector(s) }\end{array}$ & Vertebrate host \\
\hline Kay et al. [9] & $\begin{array}{l}\text { Brisbane and Carseldine } \\
\text { (outer suburban Brisbane) }\end{array}$ & Agar gel immunodiffusion & Cx. annulirostris & $\begin{array}{l}\text { Common brushtail possums, } \\
\text { horses, dogs, humans and } \\
\text { birds }\end{array}$ \\
\hline Kay et al. [23] & $\begin{array}{l}\text { Mitchell River Mission and } \\
\text { Charleville }\end{array}$ & Precipitin test & $\begin{array}{l}\text { Cx. quinquefasciatus; } C X \text {. } \\
\text { annulirostris }\end{array}$ & $\begin{array}{l}\text { Dogs, macropods, cattle, pigs, } \\
\text { humans and birds }\end{array}$ \\
\hline van den Hurk et al. [1 1] & Far North Queensland & Agar gel immunodiffusion & Cx. annulirostris & $\begin{array}{l}\text { Mammals, marsupials, pigs } \\
\text { and birds }\end{array}$ \\
\hline Jansen et al. [7] & $\begin{array}{l}\text { Urban and peri-urban } \\
\text { habitats in eastern Australia } \\
\text { (Brisbane, Cairns, Newcastle } \\
\text { and Sydney) }\end{array}$ & $\begin{array}{l}\text { Enzyme-linked immunosorb- } \\
\text { ent assay }\end{array}$ & Ae. aegypti; CX. annulirostris & $\begin{array}{l}\text { Ae. aegypti had predominantly } \\
\text { human blood; Cx. annuliro- } \\
\text { stris had cattle, marsupial, } \\
\text { dog and human blood }\end{array}$ \\
\hline Johansen et al. [8] & Western Australia & $\begin{array}{l}\text { Enzyme-linked immunosorb- } \\
\text { ent assay }\end{array}$ & $\begin{array}{l}\text { Ae. camptorhynchus; } C x \text {. } \\
\text { annulirostris }\end{array}$ & Marsupials and cattle \\
\hline
\end{tabular}


reported [16, 47]. However, reports of high identification rates usually employed only fully engorged insects whereas this study utilised all insects whose abdomen appeared to contain blood of any quantity.

Mosquito collections employing $\mathrm{CO}_{2}$-baited light traps selectively attract unfed and partially blood-fed mosquitoes while fully blood-fed mosquitoes prefer to rest and thus are less attracted to $\mathrm{CO}_{2}$-baited light traps [48]. All mosquitoes studied in this project were supplied by local authority entomologists and these traps are the tool of choice in the hands of local government authorities. Typically, mosquito traps were operated overnight and insects collected the next morning, a method that, it is acknowledged, may have failed to collect diurnal and crepuscular mosquito species. Since Ae. aegypti is diurnal, this species is very rarely collected from $\mathrm{CO}_{2}$-baited light traps [49] but this species is extremely rare in the area of this study. This bias might have been minimised if it had been possible to trap mosquitoes over 24 hours using different mosquito traps and alternative methodologies [50, 51]. Targeted approaches to collecting blood-fed mosquitoes, e.g. small resting boxes such as those used by Brugman et al., 2017 [52] or large resting traps used by Sandhu et al., 2013 [53], may have yielded greater numbers of blood-fed mosquitoes and should be considered in any future studies.

\section{Conclusions}

While human-mosquito-human transmission of arboviruses like RRV can occur, this study highlights the potential importance of zoonotic cycles to the transmission of Australian arboviruses. In turn, this stresses how important it is that vector/disease control programs should be informed by an accurate knowledge of local hosts and vectors. There is sufficient novelty in the results of this study to justify the use of additional tools or techniques in a more targeted approach to a sizeable collection of blood-fed mosquitoes and the identification of their blood meal by local authorities. The low catch rates for the target group, blood-fed mosquitoes, did not enable definitive conclusions about mosquito host preferences to be drawn. However, a relatively high proportion of avian blood meals in the mosquitoes studied provides a rationale for focussing attention on wild birds as possible reservoir/amplifying hosts for Australian arboviruses.

\section{Abbreviations}

BFV: Barmah Forest virus; CDC: Centers for Disease Control and Prevention; PCR: Polymerase Chain Reaction; QLD: Queensland; RRV: Ross River virus; VIC: Victoria.

\section{Acknowledgements}

We thank Kishor Dahal and Susan Ferguson from Central Queensland University and Peter Hartt from Rockhampton Regional Council for assisting with the collection, storage and transportation of mosquitoes.

\section{Funding}

NG was in receipt of an International Postgraduate Research Scholarship and an Australian Postgraduate Award administered by Central Queensland University. The research was supported by a Health Collaborative Research Network Merit Grant and funds from the Cook Estate.

\section{Availability of data and materials}

The data supporting the conclusions of this article are included within the article. The datasets used and/or analysed during the present study are available from the corresponding author upon reasonable request.

\section{Authors' contributions}

NG, AWTR, RSB and JGA conceived the project. NG carried out laboratory experiments and drafted the paper. $\mathrm{DH}$ and $\mathrm{LH}$ collected and identified the species of mosquitoes. KL contributed to laboratory tests and data analysis. JGA supervised the project. NG, AWTR, RSB and JGA critically reviewed and revised various versions of the manuscript. RSB is co-authoring this paper in his personal capacity and his capacity as an adjunct academic at Central Queensland University. All authors read and approved the final manuscript.

Ethics approval and consent to participate

Not applicable.

Consent for publication

Not applicable.

Competing interests

The authors declare that there have no competing interests.

\section{Publisher's Note}

Springer Nature remains neutral with regard to jurisdictional claims in published maps and institutional affiliations.

\section{Author details}

1 School of Health, Medical \& Applied Sciences, Central Queensland University, Rockhampton, QLD 4701, Australia. ${ }^{2}$ Institute of Health \& Biomedical Innovation, Queensland University of Technology, Brisbane, QLD 4059, Australia.

${ }^{3}$ Mosquito Control Laboratory, QIMR Berghofer Medical Research Institute, Brisbane, QLD 4006, Australia. ${ }^{4}$ School of Health, Medical \& Applied Sciences, Central Queensland University, Brisbane, QLD 4000, Australia. ${ }^{5}$ Public Environments, Livingstone Shire Council, Yeppoon, QLD 4703, Australia.

Received: 26 November 2018 Accepted: 23 April 2019

Published online: 03 May 2019

\section{References}

1. Kuno G, Chang G-JJ. Biological transmission of arboviruses: reexamination of and new insights into components, mechanisms, and unique traits as well as their evolutionary trends. Clin Microbiol Rev. 2005;18:608-37.

2. Menkhorst P, Knight F. A field guide to the mammals of Australia. Melbourne: Oxford University Press; 2001.

3. Deakin JE, Waters PD, Graves JAM, editors. Marsupial genetics and genomics. Dordrecht: Springer; 2010.

4. Dolby T, Clarke R. Finding Australian birds: a field guide to birding locations. Melbourne: CSIRO Publishing; 2014

5. Webb C, Doggett S, Russell R. A guide to mosquitoes of Australia. Melbourne: CSIRO Publishing; 2016.

6. Hall-Mendelin S, Jansen CC, Cheah WY, Montgomery BL, Hall RA, Ritchie SA, et al. Culex annulirostris (Diptera: Culicidae) host feeding patterns and Japanese encephalitis virus ecology in northern Australia. J Med Entomol. 2012:49:371-7.

7. Jansen CC, Webb CE, Graham GC, Craig SB, Zborowski P, Ritchie SA, et al. Blood sources of mosquitoes collected from urban and peri-urban 
environments in eastern Australia with species-specific molecular analysis of avian blood meals. Am J Trop Med Hyg. 2009:81:849-57.

8. Johansen C, Power S, Broom A. Determination of mosquito (Diptera: Culicidae) bloodmeal sources in Western Australia: implications for arbovirus transmission. J Med Entomol. 2009:46:1167-75.

9. Kay BH, Boyd AM, Ryan PA, Hall RA. Mosquito feeding patterns and natural infection of vertebrates with Ross River and Barmah Forest viruses in Brisbane, Australia. Am J Trop Med Hyg. 2007;76:417-23.

10. Kay B, Carley J, Filippich C. The multiplication of Queensland and New Guinean arboviruses in Culex annulirostris Skuse and Aedes vigilax (Skuse) (Diptera: Culicidae). J Med Entomol. 1975;12:279-83.

11. van Den Hurk A, Johansen C, Zborowski P, Paru R, Foley P, Beebe N, et al. Mosquito host-feeding patterns and implications for Japanese encephalitis virus transmission in northern Australia and Papua New Guinea. Med Vet Entomol. 2003;17:403-11.

12. Chaves LF, Harrington LC, Keogh CL, Nguyen AM, Kitron UD. Blood feeding patterns of mosquitoes: random or structured? Front Zool. 2010;7:3.

13. Australian Government. Our North, Our Future: White Paper on Developing Northern Australia; 2015. http://northernaustralia.gov.au/files/files/ NAWPFullReport.pdf. Accessed 23 Jan 2019.

14. Australian Government Department of Health. National notifiable diseases: Australia's notifiable diseases status: Annual report of the National Notifiable Diseases Surveillance System. The Department of Health, Australian Government; 2019. http://www.health.gov.au/internet/main/ publishing.nsf/content/cda-pubs-annlrpt-nndssar.htm. Accessed 23 Jan 2019.

15. Newhouse V, Chamberlain R, Johnston J, Sudia W. Use of dry ice to increase mosquito catches of the CDC miniature light trap. Mosq News. $1966 ; 26: 30-5$

16. Flies EJ, Flies AS, Fricker SR, Weinstein P, Williams CR. Regional comparison of mosquito bloodmeals in South Australia: implications for Ross River virus ecology. J Med Entomol. 2016;53:902-10.

17. Townzen J, Brower A, Judd D. Identification of mosquito bloodmeals using mitochondrial cytochrome oxidase subunit I and cytochrome b gene sequences. Med Vet Entomol. 2008;22:386-93.

18. Kent RJ, Norris DE. Identification of mammalian blood meals in mosquitoes by a multiplexed polymerase chain reaction targeting cytochrome b. Am J Trop Med Hyg. 2005;73:336-42.

19. Doherty RL, Carley J, Gorman BM, Buchanan P, Welch J, Whitehead R. Studies of arthropod-borne virus infections in Queensland. IV. Further serological investigations of antibodies to Group B arboviruses in man and animals. Aust J Exp Biol Med Sci. 1964;42:149-64.

20. Doherty RL, Gorman B, Whitehead R, Carley J. Studies of arthropod-borne virus infections in Queensland. V. Survey of antibodies to group A arboviruses in man and other animals. Aust J Exp Biol Med Sci. 1966;44:365-77.

21. Kay BH, Aaskov JG. Ross River virus (epidemic polyarthritis). In: Monath TP, editor. The arboviruses: epidemiology and ecology, vol. 4. Boca Raton: CRC Press; 1989. p. 93-112.

22. Potter A, Johansen CA, Fenwick S, Reid SA, Lindsay MD. The seroprevalence and factors associated with Ross River virus infection in western grey kangaroos (Macropus fuliginosus) in Western Australia. Vector Borne Zoonotic Dis. 2014;14:740-5.

23. Kay B, Boreham P, Williams G. Host preferences and feeding patterns of mosquitoes (Diptera: Culicidae) at Kowanyama, Cape York Peninsula, northern Queensland. Bull Entomol Res. 1979;69:441-57.

24. Dixit V, Gupta A, Kataria O, Prasad G. Host preference of Culex quinquefasciatus in Raipur city of Chhattisgarh state. J Commun Dis. 2001;33:17-22.

25. Irby WS, Apperson CS. Hosts of mosquitoes in the coastal plain of North Carolina. J Med Entomol. 1988;25:85-93.

26. Kay B, Boreham P, Fanning I. Host-feeding patterns of Culex annulirostris and other mosquitoes (Diptera: Culicidae) at Charleville, southwestern Queensland, Australia. J Med Entomol. 1985;22:529-35.

27. Molaei G, Andreadis TG, Armstrong PM, Bueno R Jr, Dennett JA, Real SV, et al. Host feeding pattern of Culex quinquefasciatus (Diptera: Culicidae) and its role in transmission of West Nile virus in Harris County, Texas. Am J Trop Med Hyg. 2007;77:73-81.

28. Tempelis C, Hayes R, Hess A, Reeves W. Blood-feeding habits of four species of mosquito found in Hawaii. Am J Trop Med Hyg. 1970;19:335-41.

29. Doherty R. Arboviruses of Australia. Aust Vet J. 1972;48:172-80.

30. Whitehead R, Doherty R, Domrow R, Standfast H, Wetters E. Studies of the epidemiology of arthropod-borne virus infections at Mitchell River
Mission, Cape York Peninsula, North Queensland. Trans R Soc Trop Med Hyg. 1968;62:439-45.

31. Holder P, Browne G, Bullians M. The mosquitoes of New Zealand and their animal disease significance. Surveillance. 1999;26:12-5.

32. Lee D, Hicks M, Griffiths M, Russell R, Marks E. The Culicidae of the Australasian region. Trop Med Monogr Ser. 1989;2:207-33.

33. van den Hurk A, Nisbet D, Foley P, Ritchie S, Mackenzie J, Beebe N. Isolation of arboviruses from mosquitoes (Diptera: Culicidae) collected from the Gulf Plains region of northwest Queensland, Australia. J Med Entomol. 2002;39:786-92.

34. Cupp EW, Zhang D, Yue X, Cupp MS, Guyer C, Sprenger TR, et al. Identification of reptilian and amphibian blood meals from mosquitoes in an eastern equine encephalomyelitis virus focus in central Alabama. Am J Trop Med Hyg. 2004;71:272-6.

35. Russell RC. Dispersal of the arbovirus vector Culex annulirostris Skuse (Diptera: Culicidae) in the Murray Valley of Victoria, Australia. Gen Appl Ent. 1986;18:5-9.

36. O'Donnell M, Berr IG, Carvan T. Dispersal of adult females of Culex annulirostris in Griffith, New South Wales, Australia. J Am Mosq Control Assoc. 1992:8:159-65.

37. Azuolas J. Arboviral diseases of horses and possums. Arbovirus Res Aust. 1997;7:5-7.

38. Cloonan M, O'Neill B, Vale T, Carter I, Williams J. Ross River virus activity along the south coast of New South Wales. Aust J Exp Biol Med Sci. 1982:60:701-6.

39. QIMR Berghofer. The Queensland Institute of Medical Research twentyfifth annual report vol. 21. Brisbane, Queensland; 1970.

40. QIMR Berghofer. The Queensland Institute of Medical Research twentyseventh annual report vol. 38. Brisbane, Queensland; 1972.

41. Sanderson CJ. A serologic survey of Queensland cattle for evidence of arbovirus infection. Am J Trop Med Hyg. 1969;18:433-9.

42. Vale T, Spratt D, Cloonan M. Serological evidence of arbovirus infection in native and domesticated mammals on the south coast of New South Wales. Aust J Zool. 1991;39:1-7.

43. Doherty R, Carley J, Kay B, Filippich C, Marks EN, Frazier CL. Isolation of virus strains from mosquitoes collected in Queensland, 1972-1976. Aust J Exp Biol Med Sci. 1979;57:509-20.

44. Doherty RL, Carley J, Mackerras MJ, Marks EN. Studies of arthropod-borne virus infections in Queensland III. Isolation and characterization of virus strains from wild-caught mosquitoes in North Queensland. Aust J Exp Biol Med Sci. 1963;41:17-39.

45. Ritchie SA, Fanning ID, Phillips DA, Standfast HA, McGinn D, Kay BH. Ross River virus in mosquitoes (Diptera: Culicidae) during the 1994 epidemic around Brisbane, Australia. J Med Entomol. 1997;34:156-9.

46. Maleki-Ravasan N, Oshaghi M, Javadian E, Rassi Y, Sadraei J, Mohtarami F. Blood meal identification in field-captured sand flies: comparison of PCRRFLP and ELISA assays. Iran J Arthropod Borne Dis. 2009;3:8-18.

47. van den Hurk AF, Smith IL, Smith GA. Development and evaluation of real-time polymerase chain reaction assays to identify mosquito (Diptera: Culicidae) bloodmeals originating from native Australian mammals. J Med Entomol. 2007:44:85-92.

48. Thiemann TC, Reisen WK. Evaluating sampling method bias in Culex tarsalis and Culex quinquefasciatus (Diptera: Culicidae) bloodmeal identification studies. J Med Entomol. 2012;49:143-9.

49. Fay RW, Prince WH. A modified visual trap for Aedes aegypti. Mosq News. 1970;30:20-3.

50. Njiru BN, Mukabana WR, Takken W, Knols BG. Trapping of the malaria vector Anopheles gambiae with odour-baited MM-X traps in semi-field conditions in western Kenya. Malar J. 2006;5:39.

51. Reiter P. A revised version of the CDC gravid mosquito trap. J Am Mosq Control Assoc. 1987;3:325-7.

52. Brugman VA, Hernández-Triana LM, England ME, Medlock JM, Mertens PP, Logan JG, et al. Blood-feeding patterns of native mosquitoes and insights into their potential role as pathogen vectors in the Thames estuary region of the United Kingdom. Parasite Vectors. 2017;10:163.

53. Sandhu TS, Williams GW, Haynes BW, Dhillon MS. Population dynamics of blood-fed female mosquitoes and comparative efficacy of resting boxes in collecting them from the northwestern part of riverside county, California. J Glob Infect Dis. 2013;5:15-8. 